\title{
The affirmation of image and maps in the modern age: cartographic secularization and Protestant Reformation
}

\author{
Alessandro Ricci ${ }^{1}$ \\ Received: 5 November 2020 / Accepted: 31 December 2020 / Published online: 19 January 2021 \\ (c) The Author(s) 2021
}

\begin{abstract}
The contribution aims to focus the attention on the consequences on the use of images and in particular on the cartographic ones deriving from the Protestant Reformation. Analysing the debate around images which originated during the sixteenth century from Luther's revolution, the article tries to answer how much the Reformation contributed to change the main aspects of mapmaking in a more realistic and secularized way. Three main questions will be posed: how much did the Protestant Reformation contribute to the affirmation of the cartographic images, to the pushes towards realism and to reality? How much did the way of representing the world change, standing on the innovations promoted by the European Protestants? Did the Reformation have also consequences on the Counter-Reformation way of depicting maps? Starting from the main literature, which focused the attention on the effects of that debate about the artistic images, a parallelism with the use of new cartographic models will be proposed, wondering if the Reformation contributed to the modern way of mapmaking, overpassing the religious, metaphorical of the medieval models.
\end{abstract}

Keywords Cartography $\cdot$ Reformation $\cdot$ Secularization $\cdot$ Modern age $\cdot$ Image

\section{Introduction}

With the discovery of America and the European openness to the Atlantic Ocean and to the Mundus Novus, deep changes in the knowledge of the world, in the control of the new territories and in the cartographic representations happened. That process represented both a spatial revolution (Schmitt 1974) and a radical transformation in the way of thinking and representing the globe: indeed-as stated by Martin Heidegger- «The fundamental event of modernity is the conquest of the world as picture. From now on the word "picture" means: the collective image of representing production [das Gebild des vorstellenden Herstellens]» (2002, p. 71). The introduction of that kind of approach, based on the centrality of image in narrative and political

Author Alessandro Ricci has been awarded by the Accademia Nazionale dei Lincei the 2018 Carmelo Colamonico Prize for papers on Geography.

Alessandro Ricci

alessandro.ricci@uniroma2.it

1 Department of History, Culture and Society, University of Rome "Tor Vergata", Via Columbia, 1, Rome, Italy discourses, was also proper of the Flemish context in the late Middle Age. During that period, a modern methodology in the representation of icons and religious images was introduced, also due to the new techniques used in the way of representing things and people: «in turning toward the era, one is tempted to continue the narrative in the form of social history. One can also ask, however, what directions the visual media took in expressing the new functions. In some cases, new techniques, such as the woodcut and the engraving, which allowed the production of cheap devotional objects, were used to satisfy the increased demand for private images» (Belting 1994, p. 410).

The image was indeed the synonymous of modern age and of its implications and geographers were at the centre of that transformative process: «the task of producing the Weltbild, the 'world-picture' of the Neu-Zeit, is no longer (pace Heidegger) the responsibility of metaphysicians is no but of geographers and mariners» (Marramao 2012, p. 22), who acquired skills and competences which used to be almost only symbolic and metaphoric in the earlier period.

That revolution regarded every representation field, the artistic and cartographic ones in particular, which found their essence and their primary field of expression in the 
image. ${ }^{1}$ That was not only a simple conceptual passage, as superficially as can be interpreted: it was a revolutionary transition, firstly based on the parallel and progressive process of abandoning the religious and dogmatic canons, which characterized life and society during the Middle Age. That was the process of secularization, which involved society in its different aspects, regarding the expressive and figurative spheres, the cartographic one included.

This can be defined as the cartographic secularization: the most evident synthesis of a profound change, of a crisis, a moment of transition, which started with the transformation of medieval people landmarks that were all centred on a religious vision of the world and represented on maps in this way.

As David Woodward stated, the world in medieval times was described according to what was stated in Biblical texts, in the references of the Catholic world and by the fathers of the Church (Woodward 1987, p. 286). It was, therefore, a layered representation mostly based on written sources rather than figurative ones. The main sources were indeed the written texts: this is not a secondary aspect, considering what Heidegger affirmed about modernity. The travel experience became a priority element in the construction of the image of the world only at a later time: after the great discovery travels which changed the world representation. It is indeed quite common to find mistakes regarding toponymy and the exact location of places on earlier maps. That is because the truthfulness of the image was secondary to the metaphoric aspects, which was of primary importance in the medieval mappae mundi intended for different types of public and which corresponded to various expressive canons.

The elements which determined the cartographic secularization were the Discovery of America and the Re-Discovery of Claudius Ptolemy, but how much did the Protestant Reformation contribute to the affirmation of the cartographic images, to the pushes towards realism and to reality? How much did the way of representing the world change, standing on the innovations promoted by the European Protestants and, maybe, by a new conception of territory?

The question is of primary importance and some answers will be proposed hereafter, trying to keep distance from the wide line of research about the significance, genesis and evolution of the Reformation. ${ }^{2}$

\footnotetext{
1 At this purpose see the other work focused on that: Ricci (2018).

2 On the geographical origins of the Reformation, please see the Lucien Febvre's works present in Burke (1973).
}

\section{Reformation, individualism and geographical egocentrism}

The Reformation was part of a more general context of substitution of past certainties with renewed truths, deriving from the contestation of the ecclesiastic centres from a geographic, political and, obviously, religious points of views. This was also evident in the cartographic field, which went through the process of secularization and centralization of individuals as a consequence of Luther's ideas, parallel to a new vision of territory, based on the Protestant's idea of a gift given from God. How much, even if mostly only on a symbolical way, did the contestation of the geographic centre of Rome and of the altars into churches have effects on the destabilization of the medieval way of mapping? The medieval mappae mundi were mostly oriented to the East, according to a precise religious and dogmatic way of thinking which presented a substantial overlap between God and the Sun. In the Benedictus (Song of Zecharia), this concept is well explicated: «in the tender compassion of our God/ the dawn from on high shall break upon us/to shine on those who dwell in darkness and the shadow of death/and to guide our feet into the way of peace». Christ is the rising sun who will come back to shine upon those who are in the darkness, guiding them «into the way of peace». This analogy is also evident in the architecture of churches: the altars are usually oriented towards East in order to turn worshippers' heads towards the rising sun. The Corpus Christi coincides with the sunlight, with the divine ray. This is a powerful symbolism, with a strong visive impact able to guarantee an existential certainty also visible on the maps.

As well stated by Micheal Kunzler, in ancient churches, the orientation of the celebration was towards Orient, not only for the celebrant, but also for all the believers. If the entrance door was placed to the East, the celebrant was standing "behind" the altar facing the community, but he could only see their backs, due to the position of the community, which was also standing towards East during the prayers. The orientation of the celebration was starting to take place versus altare because more and more churches were built towards East (Kunzler 1996, p. 229).

It was not a message too distant from common people's mindset: that was a profound and pervasive metaphorical image, well understandable even by simple and illiterate peasants, whose life was ordered by the cosmic and solar rhythms, which were present into the medieval maps. The medieval maps were full, both implicitly and explicitly, of this anagogic message: for example, the mappae mundi were oriented to the East, in order to give an existential certainty that was also linked to religious truths like those stated in the Song of Zecharia. It is well exemplified by the Hereford Mappamundi, in which the orientation is towards East, 


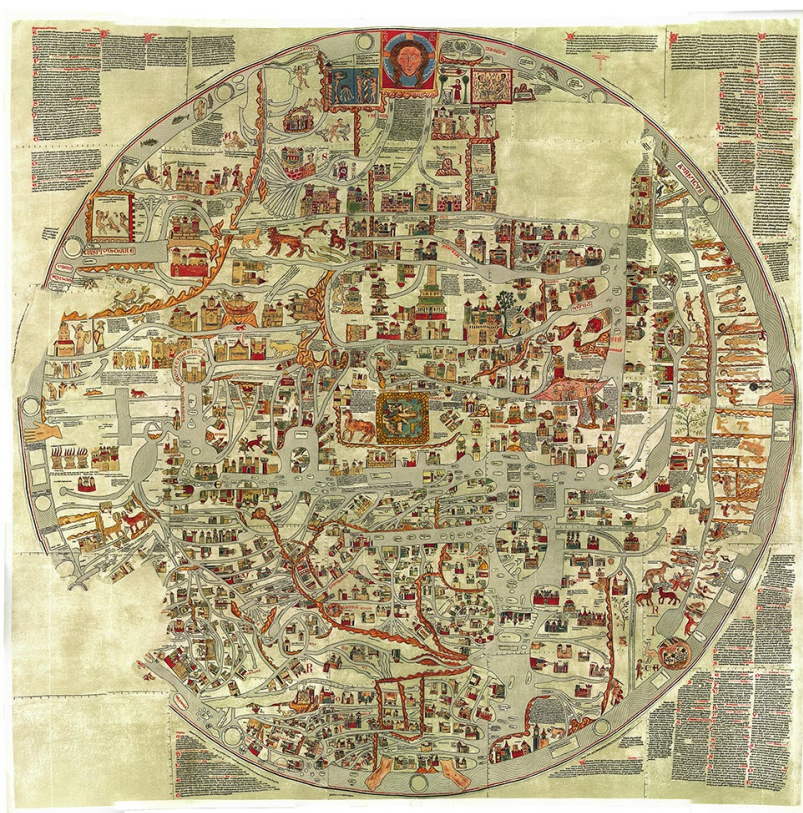

Fig. 1 The Hereford Mappamundi (1300 ca.), centred on Jerusalem. Source: wikimedia.org

Jerusalem is at the centre and-among other symbolic elements - there is a pervasive horror vacui, standing on the religious way of intending the world reality in its complexity (Fig. 1).

In the medieval world, there was a perfect overlap of metaphysic certainties and cartographic representation. How did it change because of the protestant Reformation? It seems that the Lutheran doctrine gave a strong impulse in the process of cartographic "individualization" and "egocentrism", in idealistic terms but also in terms of cultural humus and forma mentis, due to the Reformation. New maps were created in the reformed contexts, which differed from those of medieval times: in these new maps, the centre and the orientation were not given in absolute and conventional terms anymore. They started to be arbitrary, standing on a logic of personal or national interest, referred to the single sovereign who committed the maps. This was the typical mechanism of the modern age and maps reflected what Luther stated in the religious field: the lack of an established centre substituted by new centres, which can also be seen in the architecture of churches.

The architectural structure of the churches will radically change in the reformed contexts, starting with the debate launched by Zwingli and Calvin around the real presence of Jesus Christ in the Eucharist and, in parallel, from the process started by Luther on the primacy of the word, and so of the sermons. In fact, Calvin did not only removed the devotional and iconic images from the interiors, but he worked on changing the value that was given to those elements by their sacred role and the assets of the interiors, removing the altars, the choir space and changing the disposal of the seats and of the pulpit, giving much more space and a stronger role to the people (Bellini 2018, p. 87).

According to this, even the interior space of churches changed in the Lutheran context. There will not be a focal centre anymore, which remains established in the catholic context, but two different centres will emerge. One represented by the same altars, the other one was the pulpitcentral and elevated in the protestant churches-which is the place from where the pastors' words could be better spread to all the assembly. Catholics reduced the relevance of the pulpit, while Protestants contested the importance of the altar, establishing a new one, giving more centrality to individuals (Halgren Kilde 2008, p. 117).

The Reformation originated from two main factors. The first one was the possibility given by the printing innovations to spread translated versions of the Bible: this represented the first step in the process of breaking with the centralistic and universalistic vision of the Catholic Church, geographically centred on Rome (and, in parallel, on Jerusalem) and linguistically on Latin. The second one was the individualism, which also pervaded the political-geographical field. The important role that the newly invented printing press played in the changes occurred because of the Reformation has been fully well described: «the printing of pictures, however, unlike the printing of words from movable types, brought a completely new thing into existence-it made possible for the first time pictorial statements of a kind that could be exactly repeated during the effective life of the printing surface. This exact repetition of pictorial statements has had incalculable effects upon knowledge and thought, upon science and technology, of every kind. It is hardly too much to say that since the invention of writing there has been no more important invention than that of the exactly repeatable pictorial statement» (Ivins 1953, pp. 2-3). This convergence between word and image was not secondary, it was crucial and it gave to representations new impulses without decoupling it from words, which kept on being the primary sources for images. God's words embodied the renewed certainty of the Protestant world which was distant from the medieval and Catholic one: it was not a case that «it was visible support of the Reformation when he made the monogram "VDMIE" (Verbum Domini Manet In Eternum) from the Latin text of the First Epistle of St. Peter: "the word of the Lord endures forever" [...]. The device VDMIE, which later adorned the portal of Dresden castle, was a formula invoking the word as the last refuge in a time of uncertainty» (Belting 1994, p. 467).

The medieval settlement was based on the recognition of a unique ordering centre: this was valid in all senses and pervaded all the other elements in the universal and imperial architecture: no space was left to particularity, individuality, singularity neither in a geographical and political sense nor 
in the personal field, but only as a part of a wider and organic whole. This kind of approach gave meaning to the more general frame of universalistic and centralistic harmony derived from the establishment of a geographical and religious pivot, which was also represented in maps. The progressive failure of a language that could be valid for all, therefore universal, and the failure of a unique translation of the Bible, in Latin, gave substance to some of Luther's theses, such as the one regarding a personal and subjective interpretation of Christians' sacred texts.

Although radical, controversial, discussed and far-reaching, that was not only a dogmatic, linguistic and interpretative change. The one started by the Reformation was a revolution that involved also the way of approaching the things of the world, civil society and political matters. The dominant topic of the European political scenario during the sixteenth century-the political individualism coinciding with the specific religious confession, as stated by the Peace of Augsburg in 1555 with the formula Cuius Regio Eius Religio-will find his confessional reason in the possibility of finding a singular interpretation of the sacred texts, just like the Protestant Reformation guaranteed. These were two parallel processes: the principle of the «confessional individualism» of interpretation preceded the establishing the «political individualism», as it is summarized in the abovementioned formula.

This passage was well clarified by Lucien Febvre, who explained the transfer from the personal sphere to the political one, referring to the sovereign's action on his territories and to his destiny in the defence of his religious confession and in the reformation of Catholic Church. That is why citizens started to fight with a different spirit, a national consciousness that coincided with a specific confessional belonging (Burke 1973). The two spheres of the human action did not exclude each other. On the contrary, they were strictly interlaced: two worlds - the political and the religious ones-which coincided in the well-known concept established by the Peace of Augsburg. Febvre underlines that: «at the beginning of the sixteenth century, at a particularly interesting moment in the evolution of human society, the Reformation was the outward sign and the work of a profound revolution in religious sentiment. Of course, there is nothing surprising in the fact that it expressed itself in the creation of new churches, each of which prided itself on a particular creed, a set of dogmas carefully put together by its theologians and a minutely defined ritual established by its body of ministers; any invisible church tends to take shape sooner or later as a visible church» (Ibidem, p. 59).

This settlement, which had enormous consequences on the European structure of the sixteenth century, reordered the previous political and geographical balances that were proper of the medieval order, although it was unstable, mobile and not static. It also contributed to the other matter of the Reformation that was of primary importance: the Justification by faith. Every man could interpret the sacred texts by himself, without the intermediation of a priest, of a pontifex considered as a mediator between Earth, Sky and the Bible.

Old certainties were substituted by new guarantees and it happened during the sixteenth century: «but this same age and these same men, who were especially eager for certainty, since they felt the age-old foundations on which the life of their ancestors had been based beginning to crumble away, were given something else by the Reformation that was able to satisfy practical minds enamoured of sincerity and simplicity. In stating that faith alone could provide justification the Reformation was providing a new and powerful means of satisfaction for certain deep-seated tendencies» (Ibidem, p. 75).

An individual satisfaction, personal and particular even in a collective sense that will find a concrete representation also in maps and in paintings in European Palaces, which were the most evident instruments and symbols of power, as well exemplified by the case of Palazzo Farnese in Caprarola.

The Reformation started by Luther contributed to the European internal destabilization: not only in the religious field, but also in the geopolitical scenario of the European context (Troeltsch 2019). That was a characterizing element of the Modern Age, because it put in crisis the certainties of the Catholic world (Ricci 2017) and because it contributed to change deeply the theological and existential views of life. That was a centrifugal push emerged with Luther and his contestation of an established centre.

Indeed, Febvre well underlines that for the Churchmen who criticized the abuses and the sale of indulgences, «the point for them was not to study sympathetically, with no ulterior motive, the genesis of a new state of soul which roused thousands of believers, thirsting for certainty» (Burke 1973, p. 47). The problem concerned more the political character and the particular «interest»: «as men of the church their intention was above all to them in the Reformation was not the religious element, it was the ecclesiastical element, the rupture with Rome and the birth of the new churches, a fact which was of prime importance» (Ibidem).

\section{Iconoclasty and desacralization of images}

Alongside this process of individualization of the personal religious and political experience in a collective sense, concerning the birth of the Nation States identified in a confession, the reformed Church had to show its renewed 
face also in the ecclesiastic structures. Images, intended as instruments used by the Catholic Church in order to build consciences and as symbols of an old approach to the cult, should have been removed from churches. ${ }^{3}$ This also may have had consequences on the limitation of maps' production in the Protestant contexts. The contestation of images could have limited the production not only of sacred images, but also of maps: this can appear in a comparison between the numbers of maps produced in the Catholic contexts and in the Protestant ones, where the iconoclasm has been more virulent, and mostly during the sixteenth century. Whether this was visible in the first phases of the Reformation-probably mostly due to the political and social tumults and chaos derived by the Protestant movements, notably in the Northern contexts, less in the Imperial ones-during the seventeenth century, it radically changed. A felix industry was indeed visible and developed in the Northern Europe, particularly in the Netherlands, which became the greatest factory of maps in the world (Quaini 2006).

The sacred images, as well as the cartographic ones, were not excluded by the waves of Luther's 95 theses. They were integral part of the internal debate of the Reformation. Susanna Ricci well resumes the more general Lutheran approach towards the sacred images in three different phases: the first was characterized by a substantial indifference by Luther's part about the iconoclastic movement started by Gabriel Zwilling and Andreas Carlstadt; then, he became contrary to iconoclasm and he forbade it, because in his opinion, the problem was not linked to the images themselves, but to their idolatrous use; during the third and last phase, which is explained in his book The small catechism (1529), he totally approved the images, imposing some rules on their use and defining them as fundamental for the faithful (Ricci 2017). According to Luther's theory, images should not be forbidden, but they could be used without being idolized. In the controversy with Carlstadt, he underlined: «and I say at the outset that according to the law of Moses no other images are forbidden than an image of God which one worships. A crucifix, on the other hand, or any other holy image is not forbidden. Heigh now! You brokers of images, I defy you to prove the opposite!» (Stechow 1989, p. 130).

In Luther's opinion, images could be admitted only for a personal use, in private, not in public structures nor in ecclesiastic ones. Furthermore, they could be contemplated only if they reproduced God's work and they always had to be accompanied by verbum Domini. He wanted to outline the primary role of the word compared with images, although

\footnotetext{
${ }^{3}$ For a more detailed analysis about the medieval iconography, see Frugoni 2010.
}

the final result was a major role of images intended in their realistic sense. Images became the subject of a new aesthetic determination, for which the rules of art apply. That is why also the «good works» question was exclusively faced in relation to the images and in particular to Luther's opinion on iconoclasm (Vargiu 2018, p. 32).

From this conceptual settlement, the reformed art was developed in Lucas Cranach's workshop, who was the first to artistically elaborate the new themes and the renewed conception of images elaborated by Luther, starting from the dualism between Law and Grace. The technique of woodcut was elaborated behind Luther's ideology of a social low profile, far from the wealth showed by the Catholic Church. It was the less academic among the representative techniques and so it responded very well to the Lutheran doctrine ${ }^{4}$ and to the Lutheran renewed approach to creation, considered as a «categorical gift», in a sort of «theology of creation» (Bayer 2010, p. 453).

The dispute about the use of images between Luther and Carlstadt was fervent. From his part, Carlstadt intended iconoclasm as an essential moment in the general awareness, that had to be translated into concrete action. Luther, on his part, considered iconoclasm as a danger that had to be monitored because it could have possibly been the triggering factor of a repression of the Protestant movement by the sovereigns. Zwingli represented the intermediate part between iconoclasts and iconophiles (Belting 1994). In Luther's opinion, the images and the cult of images could not have a salvific purpose, whereas he considered the iconoclasm proposed by Carlstadt as a sort of reversed cult of the images that gave them a role they should not have. Indeed, in contrast with Carlstadt, Luther underlined that: «I approached the task of destroying images by first tearing them out of the heart through God's Word and making them worthless and despised. This indeed took place before Dr. Karlstadt ever dreamed of destroying images. For when they are no longer in the heart, they can do no harm when seen with the eyes. But Dr. Karlstadt, who pays no attention to matters of the heart, has reversed the order by removing them from sight and leaving them in the heart» (Stechow 1989, pp. 129-130).

Carlstadt integrally referred to the Bible, reading exactly the first commandment in the Exodus' words (20.4): «you shall not make for yourself an image in the form of anything in heaven above or on the earth beneath or in the waters below», linked to the precedent words: «you shall have no other gods before me». Carlstadt's reading was radical, as well as the Tauler's one, who considered the acquisition of images as an occupation of God's role.

The process of iconoclasm more generally hit both the artistic field and the cartographic one, in a more extensive

\footnotetext{
${ }^{4}$ See Presezzi 2017, p. 56.
} 
way. The iconoclastic fury originated because images, as artificial and imperfect elements were considered as idles. For the iconoclasts, a real icon should have been consubstantial to its model, similar to it, and that was impossible. For the iconophiles, at the contrary, this could have been made possible by a precise pictorial canon, which connected the icon to its model. In this way, a secondary role was given to the artist's activity, and a primary role to an ethic doctrine of the eye, which made it possible to distinguish the veneration of the image [proskynesis] and the adoration of it [latreia], which is due only to God, as established in the Second Council of Nicaea (Lingua 2006, p. 18).

For this reason, and for other doctrinal differences, Luther went against Carlstadt defining him an arrogant. He used strong words against the destructors of the images, who acted without authority, pushed by low instincts, inflaming the plebs and showing no sanctity and only pride.

Iconoclasm was not only a doctrinal matter, based on the reading of sacred texts. It turned into action in 1522 in Wittenberg, when Zwilling and Carlstadt strongly requested the removal of the sacred images during the Council of the Municipality and they took control of the city as promoters of disorders. The first demonstrations against the images regarded not only doctrinal aspects, but they also had a strong social-political connotation. The two leaders thought they were preventing a real iconoclasm, while in practice, through their writings and predictions, they actually promoted it with a strong radicalism (Lortz and Iserloh 1969).

Luther wanted to follow a more institutional way to affirm his reformed principles, far from the social tensions which would have been an obstacle for the full accomplishment of the proposed actions (Gallas 1999, pp. 47-56). That is why there was an open debate against Carlstadt, Zwilling and Müntzer, resumed in the sermons held after his return to the city, on 9 March, $1522 .{ }^{5}$ He considered them as bad prophets, because of their propensity to create disorder in the city and, more in general in the reformed and «recognized» settlement that he was creating. He stated: «I have allowed and not forbidden the outward removal of images, so long as this takes place without rioting and uproar and is done by the proper authorities» (Stechow 1989, p. 130). The obsession of iconoclasts against the images pushed them to act with pride, without spirit nor faith, with presumption and to avert souls from the real and more pressing problems of salvation. In Luther's opinion, their responsibility was enormous, because they created sins and questions of consciousness where they did not exist, killing souls without necessity.
From this perspective, the most evident and negative consequence of the iconoclast radical movements would have been to give a new doctrinal relevance to the «works» and to the «free will». This is the central debating question between Luther and the iconoclasts. Luther was against the adoration of images, in reference to what Moses said and to the first commandment. He was not against the images in themselves (except from the representations of God), but he considered the adoration of images as an act against God's will. Crucifixes and other sacred images were not forbidden (Ibidem). Nevertheless, Luther proposed a real desecration of images, in a secularized wave, which was a characterizing element of the protestant movements, ${ }^{6}$ behind the internal debate about the doctrinal aspects that was part of the Christian world.

Another important episode in the iconoclastic fury was represented by the revolt occurred in Münster in 1534. In this case, the rebellion had also political and social sides, against the wealth of the sovereigns symbolized also by the images: real richness was not into images, but only in the hearts of human beings, considered as living temples of God. Another important moment was represented by the facts occurred in Geneva in 1535, when the bishop was thrown out as the lord of the city and was replaced by a new regime, based on the Church of the origins, in which the religion made of images was prohibited, far from the «tyranny of the Roman antichrist» (Belting 1994).

The first iconoclastic movements were born right under the dogmatic pressure of Luther's theses on the use of images, referring to the sacred texts and, in particular, to Moses words about the two types of images. That was not a duality between sacred and profane images that had to be banned because of their intermediary function, but between images intended in a new sense and images intended in an old sense. The first typology included the images intended as sacred symbols, the second one regarded the images considered only as an artistic product, desacralized.

This distinction appeared in its most evident ways in the reformed contexts that went over Luther, where the churches were stripped of the sacred images intended as instruments of devotion. It should have been the evident sign of the purity of the new confession, standing on a renewed perspective of the Christian religion, in which images were considered not as intermediaries between the divine and the human anymore, but in their aesthetic function. In the Italian and, more in general, in the Catholic realities, images were considered in their sacred functions, although the correlation with the ability of artists was strong as much as in the reformed contexts.

$\overline{5}$ See Luther $(1961)$.

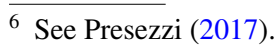


Fig. 2 The Mercator World Map (1587), a typical example of the modern and Dutch way of mapmaking during the Modern Age. Source: wikimedia.org

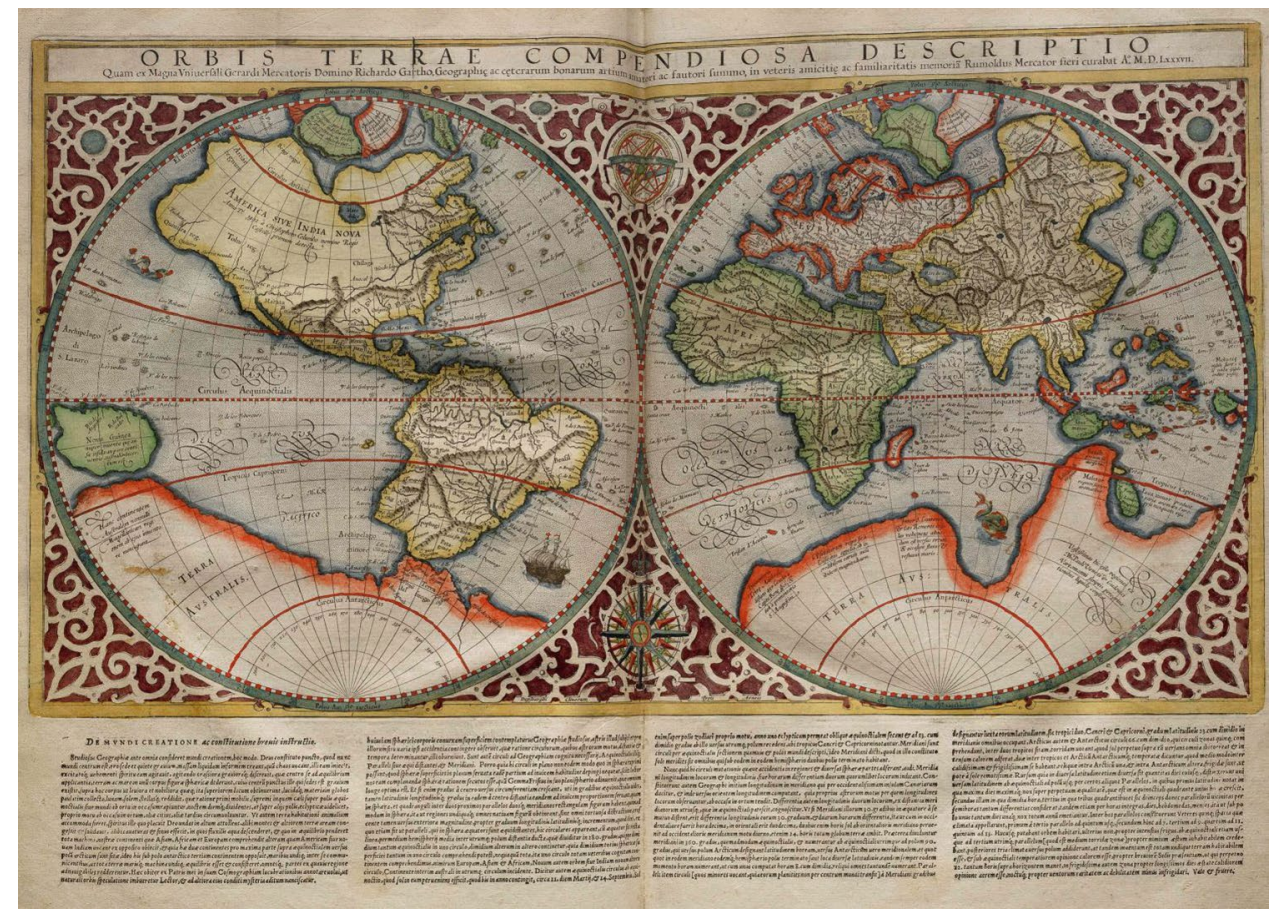

\section{The artist, the mapmaker, the genius}

What is interesting to underline is that images were adherent to a realism which appeared in a «timid» way during the fifteenth century. Art and, more in general, images were not interlaced to the divine and sacred spheres: this was the most evident innovation of the new way of interpreting art promoted by the Protestant Reformation. That was a revolution which regarded all the images and both the artistic and the cartographic models and which will have consequences also in the Catholic realities.

On the one hand, a secularization or desecration of images in art and cartography was evident, because of the internal debate to the protestant reality. Both in the violent form expressed by the iconoclastic movement and in the softer way interpreted by Luther and his writings, the most evident consequence of the theological, political and social debate was the progressive detachment of art and imageseven the cartographic ones-from the spiritual sphere. The effects of Luther's and Carlstadt's actions, even considering their dogmatic differences, were the same: to separate the human and the divine, to make the image a «neutral» instrument without a transcendental significance. Although they differed in the way of thinking regarding the role of images both of them have contributed to change the mentality of the sixteenth century, in terms of a secularization of images, as the Dutch cartography well testifies in its maximum examples of Modern cartography and atlases, such as Mercator (Fig. 2). ${ }^{7}$

On the other hand, besides this process of renovation of the significance of images, in a secularized direction, a progressive subjectivation in art and cartography emerged and affirmed. In the loss of the medieval certainties, in the contestation of a centre, in the affirmation of the individual ability to interpret the Bible, a new vision of the world of art and geographical reality and representation, in a more subjective way, took form.

With the loss of the cartographic characteristic proper of medieval times, for which the only centre was Jerusalem as a set and certain place, every point in the globe became potentially central. That process was not so distant from what the Reformation promoted, giving full autonomy to the individuals, contesting the idea of a centre and giving every human being the centrality, both religiously and, ideally, worldly. The Reformation is indeed based on the absence of centres: it finds its deepest nature in the contestation of a centre and in the process of individualism, both in religion and more in general in the approach to the knowledge of the world. The settlement of this conceptual construction was formed by the substitution of the old medieval and catholic certainties with the new ones, represented by the Protestants and by the

\footnotetext{
7 Among the others see Farinelli (2003, 2009), Quaini (2009), Ricci (2013); Schulz (1990).
} 


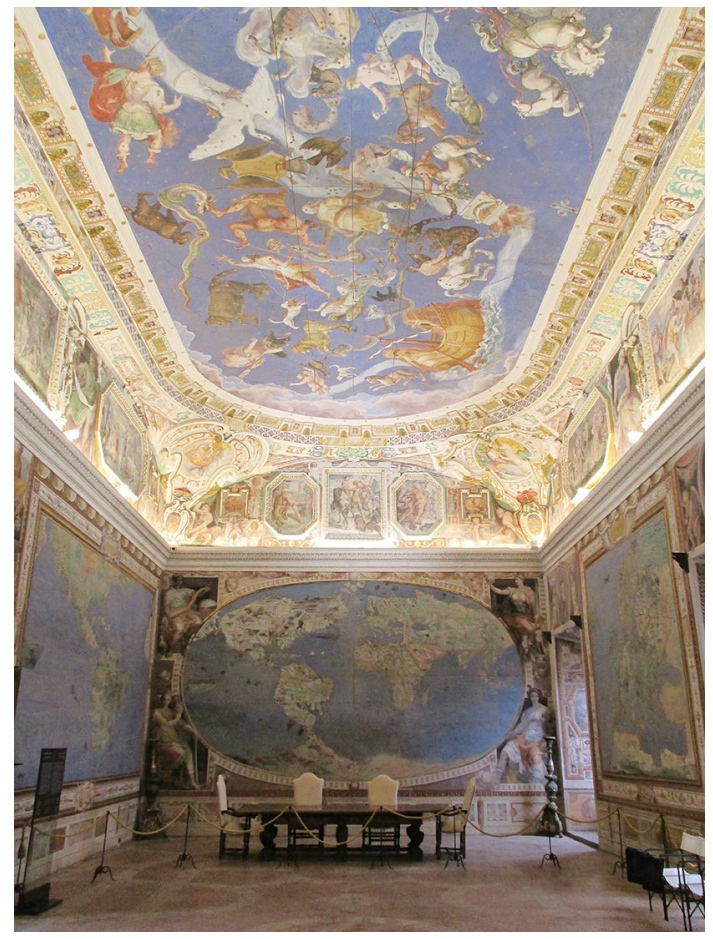

Fig. 3 The "Sala della Cosmografia" in Palazzo Farnese in Caprarola, sum of the Counter-Reformation art and Cartography. Source: wikimedia.org

Lutheran doctrine, which contributed to uncertainty with their centrifugal pushes.

In the Protestant settlement, the main role in the interpretation of the texts was given to individuals, not to the laws and precepts determined by the High. Indeed, Luca Vargiu underlines that saying to the iconoclasts that "there are two types of images" and that God did not oppose to all the images, but only to the ones which substituted him, Luther gave to the observer a new and important role (Vargiu 2018, p. 27). Individuals must interpret the verb in their own life going over the image, embodying it as a symbol of divine grace. They must bring the Christian virtues to life and stop idolizing images as symbols of sacred veneration, giving a stronger role to words and texts. In this process, a progressive secularization of images and their original sense occurred. $^{8}$

In this sense, the image became a work which did not regard just the religious field, but it was also the artist's work. Separating the image from the religious context it became a pure artistic work, the product of a genius individual, who is able to produce an artwork: «the new painting [...] now is no longer enough to tell the stories of images [...]. Images find their place in the temple of art and their true time in the history of art. A picture is no longer to be

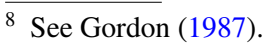

understood in terms of its theme, but as a contribution to the development of art» (Belting 1994, p. 459)..$^{9}$ This aspect was particularly evident in the artistic field, but it was also part of the most general representative settlement, including maps. In other words, although going against the idea of sacred image, Reformation gave an enormous impulse to modern art and cartography, intended in a purely instrumental and aesthetic sense. This process regarded both art and cartography in the Modern age: it was a «fascinating process whereby the medieval cult image became the artwork of the modern era» (Belting 1994, p. 16).

In this field of religious reformation, and of radical and revolutionary change of the approach on images, cartography followed two different roads. One was the Nordic and reformed path, embodied by the Dutch Calvinistic model, steeped in a strong realism according to which reality was represented in maps, as seen by the mapmaker, without cultural or religious mediation. The other one was the one represented by the Counter-Reformation, started by the Catholic Church, based on a «narrative» representation, a sum of the Catholic tradition and the cartographic modern vision, well exemplified by the Sala della Cosmografia in Palazzo Farnese in Caprarola (Fig. 3) and by the Galleria delle Carte Geografiche in Vatican (Fig. 4) ${ }^{10}$ (Schulz 1990; Gambi and Pinelli 1994; Fiorani 2005).

\section{Protestant reformation and representative realism}

How was it possible that from the dispute about images, from their desacralization and from the loss of their religious sense, in a strong and radical doctrinal diatribe on the use, prohibition and removal of images, a paradoxical primacy of the role of image itself emerged? Is it possible to affirm, in other words, that representative realism was conceptually based on the Protestant Reformation, which lashed out against images?

It is only apparently a contradiction that has to be explained and understood in its more essential aspects. The secularization of image in its double form-artistic and cartographic ones-had two main consequences. The first one was the affirmation of image as itself. The second one regards the representative realism, a new way to intend image, which finds its sense in the Lutheran doctrine and more in general in the Protestant context. These were the two

\footnotetext{
9 The aesthetic sense, which affirmed at that time, finds its significance in the transition from the concept of «good works» to «beautiful works» (see Vargiu 2018, p. 30).

${ }^{10}$ See Alpers (2009).
} 
Fig. 4 The "Galleria delle Carte Geografiche" in Vatican as expression of power, Catholic doctrine and a sum of maps and art. Source: wikimedia.org

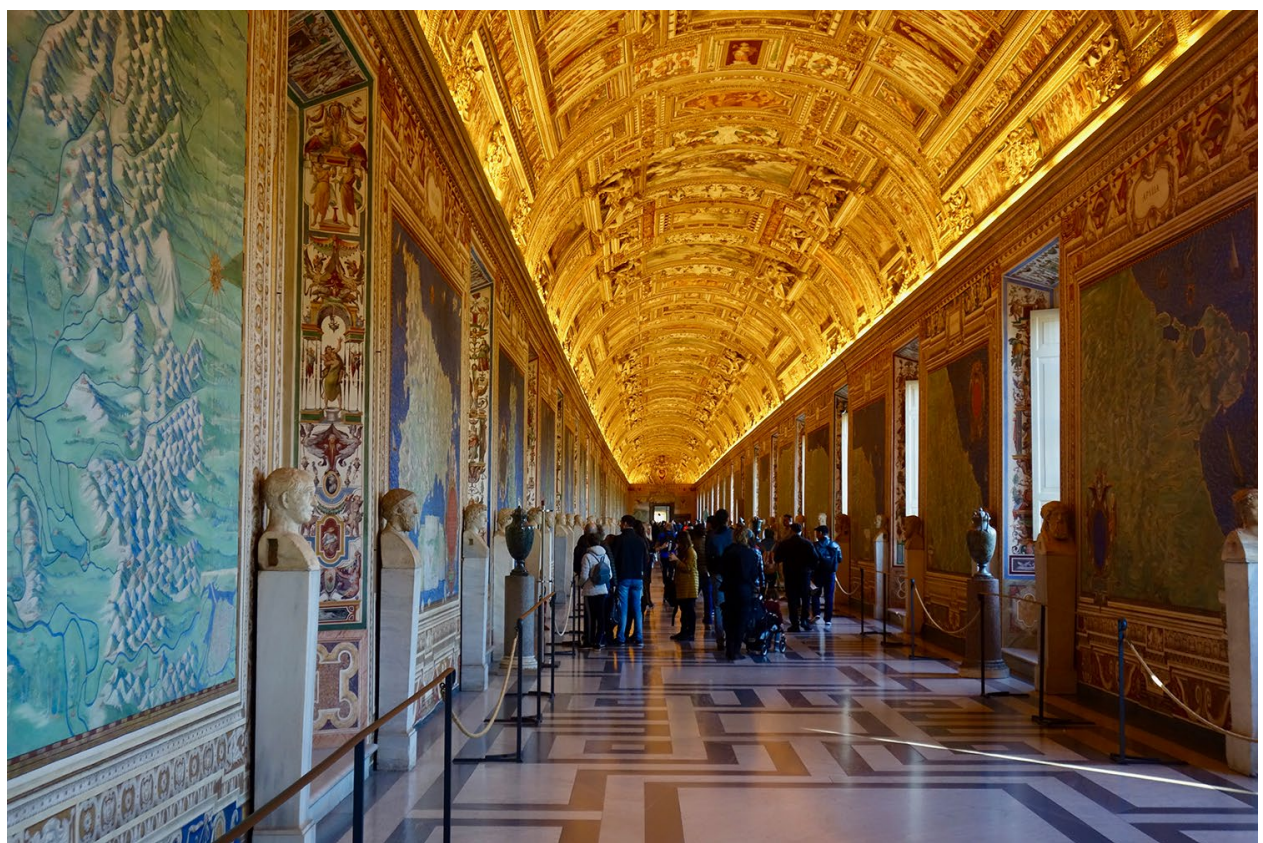

essential elements which involved all the European world, not excluding the Catholic contexts.

On the one hand, the Protestant Reformation gave full sense to the action through the grace, giving a primary role to words instead of images, on the other hand, a sort of heterogenesis of purpose emerged: depriving the sacred image of its meaning and not giving relevance to the symbolic or religious representative elements, but to the remaining realist and functional components. Because of this "desacralization of images", that was conceptual, functional and material, the Reformation propaganda was an extremely prolific period of images, spreading thousands of images repeatable, not sacred anymore but useful to spread the spirit of Reformation (Presezzi 2017, p. 53). In this passage, there is the sense of modernity as the «era of image», which finds its significance also in the Reformation advanced by Luther, although he gave more relevance to the written word. Febvre underlines that: «true, works of graphic art, which served as the books of ignorant people, were not entirely abandoned or neglected. There is hardly any Flemish painter of the time who does not show us some pious print, whether coloured or not, nailed to the wall of even the humblest room. Others were kept between the pages of Books of Hours which also served as family books and which were themselves decorated with large numbers of prints» (Burke 1973, p. 63). What Luther affirmed should have found a terrestrial coincidence between human action and the divine grace: conceptually and existentially between image, the face of Christians and their lives, between the real world and the divine. A separation between the personal and the public fields, between the internal and the external spheres, was not contemplated in the Lutheran conception. In his words, Luther accused those in which the exteriority would not coincide with the spiritual action, whereas in his opinion, the two fields - the terrestrial existence and the interior life-should follow parallel ways, in a secularized and embodied unicum.

In Luther's opinion, word and spirit should coincide and be fused together. This adherence to reality turned into a new conception of the image itself: also based on this interpretative process of the sacred texts and the Reformation of Christianism, a representative realism was affirmed. It will be a distinctive sign of art and cartography in the modern age, also deriving from a new conception of territory, considered as a gift given from God, to be used everyday in peace and to furnish bread to people. Luther stated that «you must open wide and extend your thoughts not only to the oven or the flour-bin, but to the distant field and the entire land, which bears and brings to us daily bread and every sort of sustenance» (1921, p. 185). From this renewed approach to land (that is, in any case, similar generally to the Christian one and to the Catholic one), maybe derived also a different attitude to the cartographic representation. This latter, standing on this interpretation, should be realistic, to manage lands and be adherent to reality to plan concrete strategies on its use. It is possible that this was also a crucial factor in the new ways of intending images and maps from the Lutheran perspective.

In the more general distance from the sacred images, habits, clothing, daily practices, which characterized the Catholic world as focused on the practice of faith instead of the faith itself, Luther remarked the importance of realism: «it does not help the soul if the body is adorned with the sacred robes of priests [...]. One thing, and only one thing, 
is necessary for Christian life, righteousness, and freedom» (Luther 1961, p. 54).

Luther affirmed that the grace, and with it the works, derived only from faith and the concreteness of the daily life, in which God's will should be manifested. Under this point of view, the critics to Catholicism were based on a fundamental pillar. The contradiction of the ones who, although declaring themselves faithful, did not know a real coherence in their lives. Massimo Firpo underlines that the conviction against the cult of relics, the veneration of sacred images and the other acts of worship were a basic part of the Reformation, composing a sort of "practical theology" (Firpo 1993, p. 92). At the contrary, in Luther's words, faith was something living and powerful, in which the well operates, attesting the realistic nature of adherence to reality, of the new way of interpreting Christianism. Reality cannot be understood by other instruments but the human ones. Firpo well resumes the more extensive sense of these thoughts: the justification by faith, the predestination, with their consequences gave a stronger concreteness to faith, by a direct relationship between faithful and the everyday actions, with effects on social life (Ibidem, pp. 92-93).

The transfer of this kind of mentality, of embodied grace into human beings and the impossibility of an iconic and metaphysic transfer to the artistic and cartographic world, will be largely used in the new mentality.

Since that moment the concept of image and the representative realism has strongly developed, even because of the Reformation and the innovation introduced by Luther himself: the realism of images was entering in the common sense, even due to the developments of the local churches and to their political settlement during the sixteenth century.

\section{Conclusions}

The Reformation gave a strong impulse to the formation of a modern mentality, deepening the crisis derived from the loss of past certainties based on the divine images and on the centrality of Jesus Christ, giving a stronger relevance to the realistic element in the representation. During the late Middle Ages, as Belting noticed, changes in the ways of approaching sacred images occurred, introducing elements useful to make the representation of icons more vivid and realistic. This development also occurred in Flemish paintings during the sixteenth century, as can be seen in authors such as van Eyck, who well interpreted the evolution of the concept of private image: sacred portraits represented people in their private sphere, with the consequence of a new approach to make art, which corresponds to the realism of the new conception (Belting 1994).

In that way, painting and cartography alongside had a new role: to inform men and not to form them anymore, losing its mediation function. Mapmakers and their publishers were called as the «descriptors of the world» and the atlases and maps they produced were the «world described» (Alpers 2009). Cartographic representations became the instruments used to project men towards other realities and not only towards transcendent realities. They were the tools used to control territories both physically and politically. They were not just used to imagine the world in its double dimensionof time and space-as was in the medieval maps.

Thanks to the interrelationship with science, visible in the Nordic and reformed contexts, «now the image was, in the first place, made subject to the general laws of nature, including optics, and so was assigned wholly to the realm of sense perception». As a consequence, image was considered as simulation of a "window" (Belting 1994, p. 471).

It was not a mediated and mediating image. It was a speculum mundi, a true representation of reality, an imitation produced by the interpretative genius and ability of artists and, at the same time, of cartographers.

Funding Open Access funding provided by Università degli Studi di Roma Tor Vergata.

\section{Compliance with ethical standards}

Conflict of interest No conflict of interest is involved in the contribution.

Open Access This article is licensed under a Creative Commons Attribution 4.0 International License, which permits use, sharing, adaptation, distribution and reproduction in any medium or format, as long as you give appropriate credit to the original author(s) and the source, provide a link to the Creative Commons licence, and indicate if changes were made. The images or other third party material in this article are included in the article's Creative Commons licence, unless indicated otherwise in a credit line to the material. If material is not included in the article's Creative Commons licence and your intended use is not permitted by statutory regulation or exceeds the permitted use, you will need to obtain permission directly from the copyright holder. To view a copy of this licence, visit http://creativecommons.org/licenses/by/4.0/.

\section{References}

Alpers S (2009) The art of describing: Dutch art in the seventeenth century. University of Chicago Press, Chicago

Bayer O (2010) The Ethics of Gift. Lutheran Q 25:447-468

Bellini F (2018) Riforma protestante e riforma dell'architettura religiosa. In: Biancu S (ed) Riforma e modernità. Prospettive e bilanci a 500 anni dalle Tesi di Lutero. Studium, Rome, pp 79-101

Belting H (1994) Likeness and presence: a history of the image before the era of art. University of Chicago Press, Chicago

Burke P (ed) (1973) A new kind of history from the writings of febvre. Routledge and Kegan Paul, London

Farinelli F (2003) Geografia. Un'introduzione ai modelli del mondo, Einaudi, Torino

Farinelli F (2009) La crisi della ragione cartografica. Einaudi Torino 
Fiorani F (2005) The marvel of maps: art, cartography and politics in renaissance Italy. Yale University Press, New Haven

Firpo M (1993) Riforma protestante ed eresie nell'Italia del Cinquecento. Un profilo storico. Laterza, Roma/Bari

Frugoni C (2010) La voce delle immagini. Pillole iconografiche dal Medioevo, Einaudi, Torino

Gallas A (1999) Introduzione. In: Lutero M, Contro i profeti celesti. Sulle immagini e sul sacramento. Opere scelte-vol. 8. Claudiana, Torino

Gambi L, Pinelli A (eds) (1994) La Galleria delle carte geografiche in Vaticano. Franco Cosimo Panini, Modena

Gordon DJ (1987) Renaissance imagination: essays and lectures. University of California Press, Berkeley

Halgren-Kilde J (2008) Sacred power, sacred space: an introduction to christian architecture and worship. Oxford University Press, Oxford/New York

Heidegger M (2002) Off the beaten track. Cambridge University Press, Cambridge

Ivins W (1953) Prints and visual communication. The MIT Press, Cambridge/London

Kunzler M (1996) La liturgia della Chiesa, vol 10. Jaca Book, Milano

Lingua G (2006) L'icona, l'idolo e la guerra delle immagini. Questioni di teoria ed etica delle immagini nel Cristianesimo. Medusa, Milano

Lortz J, Iserloh E (1969) Storia della Riforma. Il Mulino, Bologna

Luther M (1921) The small and large catechisms. St Polycarp Publishing House, Suwanee

Luther M (1961) Selections from his Writings. Anchor Books, New York

Marramao G (2012) The passage west philosophy after the age of the nation state. Verso, London/New York
Presezzi C (2017) Lutero: Riforma delle immagini, immagini della Riforma. In: Boeflung F, Fogliadini E (eds) La Riforma e le arti Atti del Convegno Internazionale di Studi di Villa Cagnola. Glossa, Milano, pp 53-68

Quaini M (2006) Il mito di Atlante. Storia della cartografia occidentale in Età Moderna. Il Portolano, Genova

Ricci A (2013) The art of Geographical Representation. Comparing Cartography and Art in the Dutch Golden Age. Bollettino della Società Geografica Italiana, IV:655-677

Ricci A (2017) La geografia dell'incertezza. Crisi di un modello e della sua rappresentazione in età moderna, Exorma, Roma

Ricci A (2018) Globalizzazione. Riforma Protestante e secolarizzazione cartografica, Pòlemos 2:57-73

Schmitt C (1974) Der Nomos der Erde im Völkerrecht des Jus Publicum Europaeum. Duncker \& Humbolt, Berlin

Schulz J (1990) La cartografia tra scienza e carte Carte e cartografi nel Rinascimento italiano. Franco Cosimo Panini, Modena

Stechow W (1989) Northern renaissance Art, 1400-1600: sources and documents. Book News Inc., Portland

Troeltsch E (2019) Die Bedeutung des Protestantismus für die Entstehung der modernen Welt. Oldenbourg Wissenschaftsverlag, Berlin/Boston

Vargiu L (2018) Hans Belting, l'estetica della compensazione e la Riforma. Aisthema 1:19-35

Woodward D (ed) (1987) Art and cartography. Six historical essays. Chicago University Press, Chicago

Publisher's Note Springer Nature remains neutral with regard to jurisdictional claims in published maps and institutional affiliations. 